\title{
Beef Cattle Performance on Crested Wheat- grass plus Native Range vs. Native Range Alone
}

\author{
R.H. HART, J.W. WAGGONER JR., D.H. CLARK, C.C. KALTENBACH, J.A. HAGER, AND M.B. MARSHALL
}

\section{Abstract}

Cattle gains and conception rates in 1974-1977 on crested wheatgrass pasture in spring and fall and native range in summer (CW-NR system) were compared with performance on native range throughout the grazing season (NR system). The $C W-N R$ and $N R$ systems were stocked at 0.20 and $0.10 \mathrm{AU} / \mathrm{ha}$, respectively. Conception rates on CW-NR and NR were $84 \%$ and $86 \%$, respectively, excluding results from 1975 when there were problems with heat detection; this difference was not significant. Cow, heifer, and calf gains (average of $0.30,0.41$, and $0.82 \mathrm{~kg} / \mathrm{day}$, respectively) and calf weaning weights (average of $196 \mathrm{~kg}$ ) did not differ significantly between systems. Because of the higher carrying capacity of CW-NR, calf production averaged $24.8 \mathrm{~kg} / \mathrm{ha} v \mathrm{vs} .13 .0$ $\mathrm{kg} /$ ha on NR. Other advantages of the $\mathrm{CW}-\mathrm{NR}$ system included reduced labor for heat checking and for gathering cows for breeding.

For years livestock producers in the Great Plains of the western United States have relied upon native range forage as a major feed source for ruminant livestock. However, rising production and land investment costs have forced producers to use improved grazing systems to increase efficiency of animal production. A delayed-spring-use grazing system, as defined by Heady (1969), is a system designed to delay the use of native range through the use of earlier maturing cultivated grass pastures in the spring. Delayedspring-use systems increased the carrying capacity of native ranges in the Northern Great Plains (Lodge 1970). Combinations of improved pastures and native range have improved average daily gains, reduced the acreage required per animal unit, and/or lengthened the grazing period when compared to native range alone (Lodge 1963, Smoliak 1968, Smoliak and Slen 1974). Frischknecht et al. (1953) found crested wheatgrass [Agropyron desertorum (Fisch.) Schult.] development to be 2-3 weeks ahead of development of native grasses in Utah. Rauzi (1975) concurred, noting that crested wheatgrass is best used in early spring, because a sharp decline in nutrients occurs from May through July. These results agree with those reported by Springfield and Reid (1967), Smoliak (1968), and Currie (1970).

The purpose of this 4-year study was to determine if a delayedspring-use system, combining crested wheatgrass with native range, would increase animal productivity in the High Plains region. During the experiment the following data were collected and evaluated: (1) cattle weight changes; (2) breeding performance; (3) carrying capacity and forage production; and (4) chemical composition of the spring diets of grazing cattle.

\section{Materials and Methods}

This study was conducted on the High Plains Grasslands Research Station, Cheyenne, Wyo. Average annual precipitation

Hart is research agronomist, USDA, ARS, High Plains Grasslands Research Station, 8408 Hildreth Road, Cheyenne, Wyo. 82009. Waggoner is animal nutritionist: Clark, Hager, and Marshall are former research assistants; and Kaltenbach is a nimal physiologist, Division of Animal Science, University of Wyoming, Laramie 82071 .

This study involved cooperative investigations of the USDA, ARS, and the University of Wyoming Agricultural Experiment Station.
1941-77 was $37 \mathrm{~cm}$, with 44\% falling April-June and $22 \% \mathrm{July}-\mathrm{Au}-$ gust. During the study annual precipitation ranged from $25 \mathrm{~cm}$ in 1974 to $35 \mathrm{~cm}$ in 1977 , with 62 and $83 \%$ respectively falling AprilAugust. Average frost-free growing season is 132 days. Topography of the Station is rolling hills at elevations of $1890-1950 \mathrm{~m}$.

Native vegetation is short or mixed grass prairie, dominated by blue grama [Bouteloua gracilis (H.B.K.) Lag. ex Griffiths], western wheatgrass (Agropyron smithii Bydb.), sedges (Carex spp.), and needleandthread (Stipa comata Trin. \& Rupr.), which made up 46, 18,14 , and $10 \%$ of the standing crop 1975-77 (Samuel and Howard 1982). Other plant species include prairie Junegrass [Koeleria cristata (L.) Pers.], scarlet globemallow [Sphaeralcea coccinea (Pursh.) Rydb.], and fringed sagewort (Artemisia frigida Willd.). Crested wheatgrass pastures contained nearly pure stands of crested wheatgrass [Agropyron desertorum (Fisch.) Schult.] with some smooth bromegrass (Bromus inermis Leyss.) and yellow sweetclover (Melilotus officinalis Lam.). Crested wheatgrass pastures were not fertilized.

A herd of commercial mixed breed cattle was divided each year into two herds. We attempted to balance cow, yearling heifer, and calf weights; cow and calf ages; and breeds between the herds. Mean initial weights of cattle in the NR and CW-NR herds, respectively, were cows, 442 and $435 \mathrm{~kg}$; heifers, 310 and $306 \mathrm{~kg}$; and calves, 78 nd $81 \mathrm{~kg}$. Mean cow ages in 1974, 1975, 1976, and 1977 were $4.5,4.4,3.9$ and 3.5 years, respectively, reflecting progressive culling of older cows. The CW-NR herd (see Table 1 for numbers and stocking rates) was assigned to 17 ha of crested wheatgrass for 6 weeks in May and June, then moved to 192 ha of native range from June through November. Calves were removed from the pastures and weaned 16 September 1974, 11 September 1975, 21 September 1976, and 20 September 1977. Cows and heifers were returned to the crested wheatgrass for about 6 weeks depending upon the amount of fall vegetative regrowth. The NR herd was assigned to 295 ha of native range for the entire May to December grazing period. Cattle were weighed at 14-day intervals, after a 9-12 hour shrink without feed or water, throughout the grazing season.

All cows were wintered on 51 ha of native range, part of which had been overseeded with crested wheatgrass, with hay provided as needed. A high-energy low protein supplement was fed at 0.9 $\mathrm{kg} /$ head/day during the last third of gestation, then at 1.4 $\mathrm{kg} /$ head/day from calving until spring turnout. Minerals and salt were provided ad libitum at all times.

In 1974 Hereford bulls were turned into the pastures 20 May and remained for 65 days. In 1975-77, cows coming into heat in the first 45 days of the breeding season, beginning about $20 \mathrm{May}$, were artificially inseminated. Hereford cleanup bulls were used for the subsequent 20 days. One technician was employed in each pasture to detect cows in heat and all breeding was done by one technician. Pregnancy diagnosis was by rectal palpation in the early fall, with all open cows removed from the study herds at the end of that grazing season. Heifer breeding performance is not included in the data because heifers were bred at the University Farm in Laramie, Wyo. 
Table 1. Summary of animal production on crested wheatgrass plus native range (CW-NR) or on native range alone (NR), $1974-1977$.

\begin{tabular}{|c|c|c|c|c|c|c|c|c|c|}
\hline \multirow[b]{3}{*}{ Year } & \multirow{3}{*}{$\begin{array}{c}\text { Grazing } \\
\text { season } \\
\text { (days) }\end{array}$} & \multirow{3}{*}{$\begin{array}{l}\text { Starting } \\
\text { date }\end{array}$} & \multirow[b]{3}{*}{ System } & \multicolumn{3}{|c|}{ Stocking rate } & \multicolumn{3}{|c|}{ Performance } \\
\hline & & & & \multirow{2}{*}{$\begin{array}{l}\text { Cow-calf } \\
\text { pairs }\end{array}$} & \multirow{2}{*}{$\begin{array}{l}\text { Yearling } \\
\text { heifers }\end{array}$} & \multirow[b]{2}{*}{ AUM/hal } & \multicolumn{2}{|c|}{ ADG May-Dec. } & \multirow{2}{*}{$\begin{array}{c}\text { Calf } \\
\text { production }\end{array}$} \\
\hline & & & & & & & Cow & Heifer & \\
\hline & & & & & & & & & $\mathrm{kg} / \mathrm{ha}$ \\
\hline \multirow[t]{2}{*}{1974} & 238 & 2 May & NR & 18 & 11 & .72 & .20 & .25 & 10.7 \\
\hline & & & CW-NR & 24 & 15 & 1.31 & .18 & .39 & 20.4 \\
\hline \multirow[t]{2}{*}{1975} & 233 & 3 May & NR & 18 & 8 & .64 & .12 & .22 & 11.1 \\
\hline & & & CW-NR & 23 & 16 & 1.29 & .20 & .26 & 20.2 \\
\hline \multirow[t]{2}{*}{1976} & 218 & 5 May & NR & 18 & 20 & .81 & .37 & .48 & 12.4 \\
\hline & & & CW-NR & 27 & 22 & 1.51 & .40 & .51 & 25.6 \\
\hline \multirow[t]{2}{*}{1977} & 211 & 18 May & NR & 25 & 11 & .79 & .32 & .40 & 17.9 \\
\hline & & & CW-NR & 32 & 12 & 1.39 & .42 & .49 & 32.8 \\
\hline \multirow[t]{2}{*}{ Mean } & 225 & 7 May & NR & 20 & 13 & .74 & .25 & .34 & 13.0 \\
\hline & & & CW-NR & 27 & 16 & 1.39 & .30 & .41 & 24.8 \\
\hline
\end{tabular}

IOne cow-calf pair $=1$ animal unit; one heifer $=.75$ animal unit

Herbage standing crop was determined 1975-1977 by clipping caged exclosures after cattle were removed from the crested wheatgrass (CW) pastures or during the time of peak standing crop in August in the native range (NR) pastures. Exclosures were placed in new locations each year. In 1976 and 1977, samples also were clipped outside the exclosures to estimate utilization. Esophagealfistulated cattle, kept in drylot 8 hours before each sampling, were used to obtain samples of grazed forage to determine crude protein (CP) concentration and in vitro dry matter digestibility (IVDMD) of cattle diets. Details of sampling were reported by Samuel and Howard (1982). Samples were dried in a forced-air oven at $60^{\circ} \mathrm{C}$ and ground through a Wiley mill to pass a $1-\mathrm{mm}$ screen. IVDMD was determined by the Tilley and Terry (1963) technique and CP concentration was determined by the Kjeldahl method (AOAC 1965).

\section{Results and Discussion}

Crested wheatgrass produced over twice as much herbage as native range ( $2410 \mathrm{vs} 1020 \mathrm{~kg} / \mathrm{ha}$ ). Native range produced the same amount of herbage under both grazing systems. CW herbage production in 1975,1976 , and 1977 was 2020,2800 , and $2410 \mathrm{~kg} / \mathrm{ha}$, and April precipitation in the same years was $2.3,4.8$, and $4.4 \mathrm{~cm}$, respectively. The regression equation $Y=1370+270 \mathrm{P}$, in which $\mathrm{Y}$ $=\mathrm{CW}$ yield in $\mathrm{kg} / \mathrm{ha}$ and $\mathrm{P}=$ April precipitation in $\mathrm{cm}$, accounted for $87 \%$ of the variation in $\mathrm{CW}$ yield. April + May and April through June precipitation accounted for only 47 and $6 \%$, respectively, of variation in CW yield. Currie and Patterson (1966) found that spring precipitation, particularly April precipitation, determined $\mathrm{CW}$ forage production.

Crude protein concentration of cattle diets on CW in May 1974 and in May and June 1975 were significantly higher $(P<.05)$ than those of diets on NR (Table 2). Crude protein concentations of CW and NR diets were similar in both 1976 and 1977. The IVDMD values during May were higher for $C W$ than for NR in all years,

Table 2. Crude protein concentration and in vitro dry matter digestibility (IVDMD) of cattle diets (\%) on crested wheatgrass (CW) and native range (NR) pastures in spring.

\begin{tabular}{|c|c|c|c|c|c|c|c|}
\hline \multirow[b]{2}{*}{ Year } & \multirow[b]{2}{*}{ Month } & \multicolumn{3}{|c|}{ Crude protein } & \multicolumn{3}{|c|}{ IVDMD } \\
\hline & & $\mathbf{C W}$ & & NR & $\mathrm{CW}$ & & NR \\
\hline \multirow[t]{2}{*}{1974} & May & 21.0 & * & 14.6 & 62 & $*$ & 50 \\
\hline & June & 14.6 & & 13.3 & 50 & & 52 \\
\hline \multirow[t]{2}{*}{1975} & May & 20.1 & $*$ & 16.0 & 53 & & 48 \\
\hline & June & 23.2 & $*$ & 14.5 & 50 & $*$ & 66 \\
\hline \multirow[t]{2}{*}{1976} & May & 12,4 & & 13.3 & 69 & & 66 \\
\hline & June & 12,9 & & 12.8 & 一 & & - \\
\hline \multirow[t]{2}{*}{1977} & May & 12,9 & & 13.4 & 58 & $*$ & 52 \\
\hline & June & 11.3 & & 11.2 & 53 & & 53 \\
\hline \multirow[t]{2}{*}{ Mean } & May & 16.6 & * & 14.3 & 60 & $*$ & 54 \\
\hline & June & 15.5 & $*$ & 13.0 & 51 & $*$ & 57 \\
\hline
\end{tabular}

*Indicates pastures means are significantly different $(P<.05)$. although the difference was significant only in 1974 and 1977 , indicating the high amount of a vailable nutrients in $\mathrm{CW}$ during the spring. However, in June IVDMD values for $C W$ were similar to or lower than those for NR because of the rapid maturing and subsequent decline in quality of $\mathrm{CW}$. This agreed with the findings of Cook and Harris (1952), Rauzi (1975), and Hart et al. (1983), in which they reported rapid declines in $\mathrm{CW}$ nut rients associated with advancing maturity. During lactation and breeding, nutrient levels are critical for maintaining optimum animal productivity (Wiltbank et al. 1962). Mean CP and IVDMD values of diets in May and $C P$ values in June indicate $C W$ pastures are superior to native shortgrass range as spring forage for cattle.

In 1975 cows in the NR system had a significantly higher conception rate than cows in the CW-NR system (Table 3 ). This difference may have reflected a disparity in skills of the technicians detecting heat rather than an effect of the systems. There were no significant differences between systems in conception rates in 1974 when all cows were bull-bred, or in 1976 and 1977 when the technicians exchanged pastures each day. Average conception rates were $79 \%$ and $88 \%$ for CW-NR and NR, respectively, over the 4-year period, or $84 \%$ and $86 \%$ when 1975 data were omitted; neither difference was significant. Cows that bred successfully were heavier at the beginning of the breeding season than cows that remained open (446 vs. $425 \mathrm{~kg}$ ). However, there was no significant difference in cows weights between systems. Frischknecht et al. (1953) and Houston and Urick (1972) showed that conception rates were elevated when cows were concentrated in smaller areas for heat detection or breeding by bulls, but this was not demonstrated in our study. However, labor of heat checking and collecting cows for insemination was redued under the CW-NR system.

Calf gains from birth to weaning in September increased significantly from $0.75 \mathrm{~kg} /$ day in 1974 to $0.90 \mathrm{~kg} /$ day in 1977 , reflecting the effect of herd improvement due to culling. The higher gains resulted in an increase of $22 \%$ in weaning weights from $178 \mathrm{~kg}$ in 1974 to $217 \mathrm{~kg}$ in 1977. Calf performance showed no significant differences between grazing systems in birth weights, average daily gains, or weaning weights. Average weaning weight over the entire study was $196 \mathrm{~kg}$, almost identical to the maximum weaning weight at stocking rates below the critical stocking rate (Hart 1978) in the

Table 3. Cow conception rates (\%) on crested wheatgrass plus native range (CW-NR) or on native range alone (NR).

\begin{tabular}{lcc}
\hline \hline Year & CW-NR & NR \\
\hline 1974 & 88 & 78 \\
1975 & 64 & $*$ \\
1976 & 74 & 84 \\
1977 & 91 & 96 \\
Mean & & \\
$1974-77$ & 79 & 88 \\
1975 omitted & 84 & 86 \\
\hline
\end{tabular}

*Indicates system means are significantly different $(P<.05)$. 


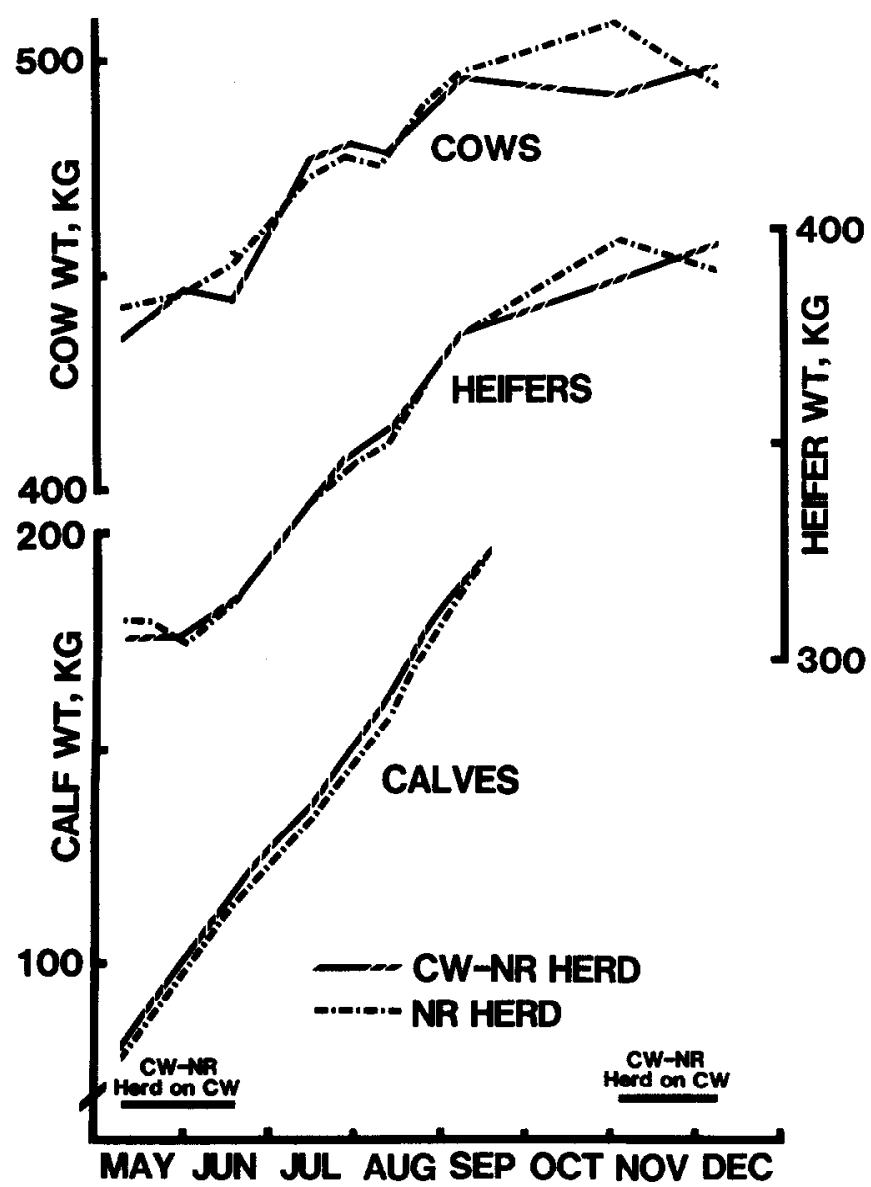

Fig. 1. Seasonal patterns of cow, calf, and heifer weights on crested wheatgrass plus native range ( $\mathrm{CW}-\mathrm{NR}$ ) or on native range alone (NR).

study of Houston and Woodward (1966). Thus stocking rates might not have been high enough to detect differences in calf weights between systems.

Cows on the $\mathrm{CW}$-NR system averaged $7 \mathrm{~kg}$ lighter than those on the NR system at the start of the grazing season, but gained faster and achieved equal weight in the first few weeks on crcsted wheatgrass (Fig. 1). As quality and availability of crested wheatgrass decreased, weights of CW-NR cows again dropped below those of NR cows. When the CW-NR cows were turned into range in mid-June, they gained faster than the NR cows, probably because more forage was available following deferral of grazing, and by July the CW-NR cows again were heavier than the NR cows. Clipping in late August of 1976 and 1977 estimated forage utilization of 18.5 and $20.6 \mathrm{~kg} / \mathrm{AU} /$ day on the range pastures of the CW-NR and NR systems, respectively. Utilization did not differ significantly between systems, suggesting that forage supply had not differentially affected intake up to this time. However, a decline in weight of the CW-NR cows in September and October indicated the higher stocking rate on this system $(0.20$ vs 0.10 $\mathrm{AU} /$ ha on the NR system) had reduced the forage supply below that necessary to maintain cow weights. By early November, just before the $\mathrm{CW}-\mathrm{NR}$ cows were returned to the crested wheatgrass pasture, they averaged $17 \mathrm{~kg}$ lighter than the NR cows. However, the CW-NR cows gained weight on crested wheatgrass in November and December, while the NR cows lost weight on the range, so by mid-December the former were $4 \mathrm{~kg}$ heavier than the latter.

Weights of heifers followed a pattern very similar to that of cows, except gains were larger and differences between systems were smaller. Heifers on CW-NR were $4 \mathrm{~kg}$ lighter than those on NR at the start of the grazing season, but weights were nearly the same on both systems from early June until early September. In
September and October, heifers on CW-NR gained more slowly than those on NR, and weighed $7 \mathrm{~kg}$ less by early November. The CW-NR heifers continued to gain after returning to crested wheatgrass pasture, while the NR heifers lost weight on the range, so by mid-December the former were $6 \mathrm{~kg}$ heavier than the latter.

Calves gained weight steadily all season long on both systems, with the calves on CW-NR $3 \mathrm{~kg}$ and $1 \mathrm{~kg}$ heavier than those on NR at the beginning of the season and at weaning, respectively. Gains were very nearly constant over the season; when the regressions of weights on dates were calculated, date accounted for .998 and .996 of the variation in weights on CW-NR and NR, respectively.

On a combination of crested wheatgrass and native range, it was possible to double the stocking rate of cattle as compared to the rate on native range alone, without reducing breeding performance or gains of cows, heifers and calves. Mean annual forage production on the entire CW-NR system was 145 metric tons (on 209 ha) vs. 168 metric tons (on 295 ha) on the NR system. Thus we carried $34 \%$ more cattle (see Table 1) on 14\% less forage; one might suspect suspect the NR system was understocked, but weight losses of cows and heifers at the end of the season suggests the stocking rate was not too low. We suggest that the higher quality and greater availability of crested wheatgrass forage during spring and late fall, traditionally periods of feed shortage on the range, were responsible for the large increase in carrying capacity. Because of the increased carrying capacity of the wheatgrass-range system, it produced nearly twice as much weaned calf weight per hectare as did native range alone.

\section{Literature Cited}

Association of Official Agricultural Chemists. 1965. Official methods of AOAC analysis (10 ed.) Assoc. Offic. Agr. Chem., Washington, D.C.

Cook, C.W., and L.L. Harris. 1952. The nutritive value of cheatgrass and crested wheatgrass on spring ranges in Utah. J. Range Manage. 5:331337.

Currie, P.0. 1970. Influence of spring, fall and spring-fall grazing on crested wheatgrass range. J. Range Manage. 23:103-108.

Currie, P.O., and G. Peterson. 1966. Using growing-season precipitation to predict crested wheatgrass yields. J. Range Manage. 19:284-288.

Frischknecht, N.C., L.E. Harris, and H.K. Woodward. 1953. Cattle gains and vegetal changes as influenced by grazing treatments on crested wheatgrass. J. Range Manage. 6:151-158.

Hart, R.H. 1978. Stocking rate theory and its application to grazing on rangelands. Proc. Ist Internat. Rangeland Cong., p. 547-550.

Hart, R.H., O.M. Abdalla, D.H. Clark, M.B. Marshall, M.H. Hamid, J.A. Hager, and J.W. Waggoner Jr. 1983. Quality of forage and cattle diets on the Wyoming High Plains. J. Range Manage. 36:(in press).

Heady, H.F. 1969. Grazing systems; objectives, definitions, controversies. Abstr. Papers Soc. Range Manage. 22:20.

Houston, W.R., and J.J. Urick. 1972. Improved spring pastures, cow-calf production, and stocking rate carry-over in the Northern Great Plains. USDA Tech. Bull. 1451.

Houston, W.R., and R.R. Woodward. 1966. Effects of stocking rates on range vegetation and beef cattle production in the Northern Great Plains. USDA Tech. Bull. 1357.

Lodge, R.W. 1963. Complimentary grazing systems for Sandhills of the Northern Great Plains. .I. Range Manage. 16:240-244.

Lodge, R.W. 1970. Complimentary grazing systems for the Northern Great Plains. J. Range Manage. 23:268-271.

Rauzi, F. 1975. Seasonal yicld and chemical composition of crested wheatgrass in Southeastern Wyoming. J. Range Manage. 28:219-221.

Samuel, M.J., and G.S. Howard. 1982. Botanical composition of summer cattle diets on the Wyoming High Plains. J. Range Manage. 35:305-308.

Smoliak, S. 1968. Grazing studies on native range, crested wheatgrass, and Russian wildrye pastures. J. Range Manage. 21:47-50.

Smoliak, S., and S.B. Slen. 1974. Beef production on native range, crested wheatgrass, and Russian wildrye pastures. J. Range Manage. 27:433436 .

Springfield, H.W., and E.H. Reid. 1967. Crested wheatgrass for spring grazing in northem New Mexico. J. Range Manage. 20:406-408.

Tilley, J.M.A., and T.A. Terry. 1963. A two-stage technique for the in vitro digestion of forage crops. J. Brit. Grassl. Soc. 18:104-111.

Wiltbank, J.N., N.W. Rowden, J.E. Ingalls, K.E. Gregory, and R.M. Kock. 1962. Effect of energy level on reproductive phenomena of mature Hereford cows. J. Animal Sci. 21:219-225. 